JURNAL MAKSIPRENEUR, Vol. VII, No. 1, Desember 2017, hal. 1-17

\title{
SHARING OF KNOWLEDGE: HAMBATAN KETERLIBATAN MAHASISWA DALAM DISKUSI
}

\author{
Yulius Aldo Bima Prasetyo \\ Tutuk Ari Arsanti
}

Fakultas Ekonomika dan Bisnis, Universitas Kristen Satya Wacana, Salatiga

Korespondensi penulis: tutuk@staff.uksw.edu

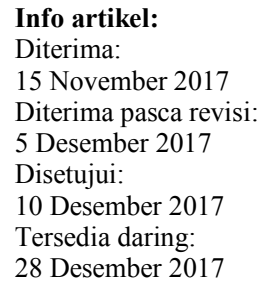

\begin{abstract}
Knowledge sharing is an important process in the development of knowledge, especialy for higher education such as universities. Knowledge sharing process can happen to students in the form of discussion. However, in the process there are several factors that hamper the process of discussion among students. This study aims to find and identify the barriers that exist in the process of discussion. Sources of data are primary obtained initially
\end{abstract} through observation then through interviews on 17 students of management program. The results of this study indicate the existence of some barriers that inhibit the process of discussion in the classroom. The barriers found in this study are identified as barriers of individual and organizational factors.

Keywords: knowledge sharing, barriers, discussion.

\section{PENDAHULUAN}

Knowledge menjadi aset penting bagi organisasi (Hansen et al., 1999), karena dibutuhkan untuk berinovasi, pengembangan strategi, maupun dalam pengambilan keputusan dalam rangka memecahkan suatu permasalahan (Nonaka, 1994; Hansen et al., 1999). Peran knowledge yang sangat penting ini mendorong organisasi mengembangkannya secara intensif untuk menjaga eksistensinya. Adanya interaksi secara intensif antarindividu untuk bertukar pikiran dapat mengakumulasi dan meningkatkan pengetahuan yang dimiliki (Nonaka, 1994; Bartol \& Srivastava, 2002). Menurut Flaxton (2013), pertukaran pemikiran tersebut termasuk bagian dari kegiatan share of knowledge. Lebih lanjut, hal tersebut dapat menjadi sarana pendistribusian informasi dan pengetahuan, sehingga menjadi aset intelektual yang berguna (Lee, 2001; Mbaso, 2005; Andolsek et al., 2015).

Perguruan Tinggi sebagai lembaga pendidikan berperan sebagai pengelola, pengembang, dan penyempurna pengetahuan (Sohail \& Daud, 2009), dan berkontribusi dalam pengembangan intelektual maupun peningkatan kognitif sejak dari tingkat individu (Liu et al., 2014). Bertukar pemikiran melalui proses diskusi dalam kegiatan belajar mengajar merupakan salah satu bentuk yang efektif dalam proses share of knowledge. Setiap partisipan dalam proses diskusi dapat 
terlibat langsung menyampaikan pendapat yang digunakan untuk menyelesaikan suatu permasalahan dengan informasi dan pengetahuan yang dikumpulkan (Parker \& Hess, 2000). Akumulasi pengetahuan yang dibentuk melalui proses diskusi dapat digunakan untuk pengembangkan pengetahuan lebih lanjut (Sohail \& Daud, 2009; Buckley 2012).

Mengacu pada model spiral of knowledge oleh Nonaka (1994) menjelaskan adanya hambatan yang terjadi dalam share of knowledge pada level individu ke level kelompok. Dengan demikian, bukan hal yang mudah untuk membagun pengetahuan bersama melalui proses diskusi yang produktif di dalam kelompok (Parker \& Hess, 2000) seperti halnya di dalam kelas. Penelitian terdahulu menemukan sejumlah barriers seperti faktor internal individu, maupun faktor eksternal seperti organisasional dan teknologi (Riege, 2005; Gider et al., 2015; Chmielecki, 2013). Barriers yang muncul pada faktor individu. misalnya adanya risiko, kemampuan kognitif, maupun tingkat motivasi dan organisasional seperti penghargaan dan kesempatan dalam berpartisipasi yang ditemukan pada hasil penelitian Riege (2005), Chmielecki (2013), Gider et al. (2015), dan Rosen et al. (2007). Hasil penelitian Riege (2005) dan Santos et al. (2012) menemukan adanya beberapa barriers pada faktor teknologi dalam proses share of knowledge.

Observasi yang dilakukan terhadap proses diskusi dan keterlibatan mahasiswa di dalamnya dilakukan selama kegiatan belajar mengajar di sejumlah kelas. Hasil observasi menunjukan persentase partisipasi mahasiswa dalam proses diskusi di dalam kelas yang menunjukkan rata-rata $12,5 \%$. Dari hasil observasi yang dilakukan mengindikasi kemungkinan adanya barriers yang terjadi dalam proses diskusi. Berdasarkan fenomena tersebut, peneliti berusaha untuk mengkaji dan mengidentifikasi hambatan mahasiswa terlibat dalam proses diskusi selama kegiatan belajar mengajar di kelas. Adanya kendala tersebut dapat menghambat pengembangan dan akumulasi pengetahuan pada mahasiswa. Penelitian-penelitian terdahulu banyak memberikan fokus perhatian dalam sharing of knowledge dalam perusahaan, sedangkan dalam kegiatan belajar mengajar di kelas masih minim dilakukan. Dengan demikian, penelitian ini mencoba untuk mengkaji hambatan dalam sharing of knowledge dalam diskusi di kelas.

\section{RERANGKA TEORITIS}

\section{a. Knowledge Sharing}

Menurut Li (2009), knowledge sharing merupakan aktivitas ketika partisipan terlibat dan masuk secara langsung ke dalam proses kontribusi, negosiasi, dan penggunaan knowledge. Dengan demikian, adanya proses pertukaran pengetahuan antara dua partisipan atau lebih dalam bentuk timbal balik, yang dapat mengasah dan menciptakan pemahaman baru akan pengetahuan tersebut (Ramayah et al., 2013; van den Hoof \& de Ridder, 2004). Penjelasan tersebut menunjukkan proses keterlibatan individu dalam bertukar pengetahuan sebagai bentuk kontribusinya dalam pengembangan pengetahuan.

Bentuk dari keterlibatan partisipan di dalam proses share of knowledge dapat berupa pemberian ide, gagasan, atau pertanyaan tentang maksud dan tujuan dari informasi yang kemudian diterima untuk digunakan ke depannya. Kegiatan diskusi merupakan bentuk yang efektif dalam share of knowledge (Parker \& Hess, 2000), karena bermanfaat untuk mencari jawaban suatu masalah atau pertanyaan (Pollock et al., 2011; Parker \& Hess, 2000). Dengan demikian, knowledge sharing 
dapat terjadi ketika individu bertanya akan pengetahuan yang ingin diketahui dari individu lain (Kharabsheh, 2007).

Diskusi menjadi wadah pada pengembangan pemikiran yang kritis, sehingga dapat meningkatkan pengetahuan individu dalam memecahkan suatu permasalahan (Pollock et al., 2011). Akumulasi pengetahuan yang didapat melalui proses sharing of knowledge, kemudian dibagikan kembali kepada individu atau pun organisasi guna mendukung inovasi yang berkelanjutan (Nonaka \& Takeuchi, 1995; van den Hoof \& de Ridder, 2004; Bartol \& Srivasta, 2002). Meski proses sharing of knowledge memberikan banyak keuntungan, tetapi dalam penelitian Nonaka, Tayuma dan Konno (2000) menunjukkan adanya hambatan dalam proses share of knowledge, sehingga dapat berdampak pada terhambatnya proses pembentukan konseptual baru yang berguna dalam pembentukan inovasi ke depannya.

\section{b. Barriers dalam Sharing of Knowledge}

Mengacu pada model spiral of knowledge oleh Nonaka (1994) menunjukkan adanya barriers yang terjadi pada tingkat individu ke kelompok. Barriers yang ada mengakibatkan pengetahuan individu tidak berkembang, bahkan mungkin akan hilang (Reige, 2005). Sejumlah faktor menjadi penghambat di antaranya faktor internal individu dan faktor eksternal individu (Nonaka \& Takeuchi, 1995). Hal tersebut dijelaskan sebagai berikut:

\section{Faktor Internal Individual}

Adanya risiko atas konsekuensi dari share of knowledge seperti munculnya rasa malu, takut, dan beban yang dipikul. Menurut Chmielecki (2013), individu mempunyai kecenderungan untuk menghindari risiko, seperti rasa malu jika terjadi kesalahan saat melakukan proses sharing of knowledge. Kekurangan akan sumber informasi juga menjadi risiko bagi seseorang, sehingga takut untuk menyampaikan apa yang dia ketahui (Reige, 2005; Barson et al., 2000). Individu juga menghadapi risiko, seperti munculnya beban tersendiri jika apa yang dibagikan tidaklah relevan dengan apa yang terjadi (Disterer, 2001).

Kemampuan kognitif yang dimiliki individu menentukan seberapa mampu ia dapat menerima dan mengkomunikasikan informasi kembali. Kemampuan memahami konteks diskusi merupakan hal yang penting agar proses knowledge sharing dapat terjadi dan sesuai dengan topik yang dibutuhkan untuk dibahas (Disterer, 2001; Bures, 2003; Reige, 2005). Sebagai contoh, bagaimana kemampuan individu dalam memahami suatu permasalahan pada topik tertentu untuk kemudian disampaikan secara verbal dan didiskusikan bersama-sama menjadi penting dalam share of knowledge. Penelitian seperti Santos et al. (2012) dan Bures (2003) menemukan kurangnya motivasi individu dalam share of knowledge disebabkan karena rasa ketidakinginan dan ketidakpedulian dengan apa yang ingin individu ketahui. Rendahnya motivasi juga dapat disebabkan karena ketidakpahaman akan keuntungan yang diperoleh dalam share of knowledge, sehingga individu tidak peduli (Disterer, 2001).

Faktor kepercayaan diri yang dimiliki individu juga berperan dalam share of knowledge. Kepercayaan diri pada individu mempengaruhi keberaniannya untuk mengungkapkan pendapat, ide, atau gagasannya (Wang \& Noe, 2010). 
Pengetahuan dan pengalaman yang dimiliki membuat individu menjadi percaya diri untuk menyampaikan pengetahuannya tersebut kepada orang lain (Santos et al., 2012; Wang \& Noe, 2010). Barriers lainnya yang terjadi dalam faktor individu yaitu adanya nilai dan budaya yang ada pada individu. Berkaitan dengan tindakan yang akan dilakukan oleh individu didasarkan pada nilai yang dipelajari oleh individu itu sendiri (Reige, 2005). Pemahaman akan perbedaan usia, tingkat pendidikan, nilai-nilai, dan hubungan sosial pada budaya yang dipahami membuat individu perlu memperhatikan secara serius bagimana cara berkomunikasinya agar tidak terjadi kesalahpahaman dengan orang lain (Bures, 2003; Reige 2005). Hal tersebut tentu menimbulkan pemikiran yaitu kesalahpahaman yang terjadi dapat berakibat pada tidak diterimanya individu di dalam suatu lingkungan atau hubungan sosialnya (De Long \& Fahey, 2000).

\section{Faktor Eksternal}

Dalam faktor organisasional sendiri, barriers yang umum terjadi dan ditemukan di dalam penelitian sebelumnya adalah kurangnya waktu dan kesempatan yang diberikan untuk melakukan proses sharing. Tidak adanya kesempatan dan waktu yang diberikan membuat individu menjadi tidak memiliki kesempatan dalam menyampaikan pendapatnya di dalam proses diskusi (Reige, 2005). Memberi kesempatan dan waktu untuk mempersiapkan proses diskusi merupakan pendekatan yang tepat antara partisipan agar dapat lebih kritis dalam proses sharing of knowledge yang terjadi (Rosen et al., 2007; Santos et al., 2012). Namun, jika tidak adanya kesempatan serta waktu yang cukup untuk melakukan hal tersebut, maka secara pasti akan menghambat terjadinya proses diskusi.

Selain itu, barriers lainnya adalah kurangnya sistem penghargaan yang terstruktur dan sistem hirarki organisasional yang membatasi keleluasaan untuk berargumen dan berdiskusi. Reige (2005) menemukan bahwa pemberian penghargaan sifatnya bukanlah jangka panjang, tetapi perlu dilakukan untuk memotivasi agar knowledge sharing terjadi secara intensif. Hal tersebut membutuhkan waktu karena untuk hasil jangka panjang membutuhkan proses yang alami dan terus menerus. Penghargaan diberikan supaya partisipan termotivasi untuk melakukan proses knowledge sharing (Gider et al., 2015). Hal tersebut menjelaskan bahwa kurangnya penghargaan membuat partisipan tidak tertarik untuk terlibat di dalam proses knowledge sharing. Beberapa penelitian memiliki argumentasi bahwa struktur organisasi yang terbuka dan fleksibel dalam pemberian penghargaan lebih mendukung akan terjadinya proses sharing of knowledge (Nonaka \& Takeuchi, 1995; De Long \& Fahey, 2000).

Hambatan lain yang ditemukan berasal dari lingkungan individu tersebut. Secara fisik maupun non-fisik, suasana sekitar individu dapat mempengaruhi aktifitas maupun kegiatannya terutama partisipasinya di dalam proses sharing of knowledge (Reige, 2005). Lingkungan sosial juga mempengaruhi individu untuk menentukan keputusannya dan tindakannya, sehingga hal itu dapat mempengaruhi keterlibatannya dalam proses knowledge sharing (Bures, 2003; Reige, 2005). Selain itu, adanya fenomena yang disebut dengan sosial 
facilitation yang menjelaskan adanya keberadaan orang lain mempengaruhi peningkatan maupun turunnya kemampuan seseorang dalam bekerja maupun hal lainnya (Huges et al., 2015). Hal tersebut dapat dipahami bahwa lingkungan menjadi hambatan dalam proses sharing of knowledge.

Teknologi tidak hanya sebagai suatu fasilitas yang mendukung knowledge sharing pada individu agar lebih efektif dan intensif tetapi bagaimana suatu organisasi memanfaatkan teknologi untuk menciptakan lingkungan yang nyaman untuk terjadinya proses knowledge sharing (Reige, 2005). Menggunakan teknologi sebagai sumber informasi menjadi solusi bagi ketidakjelasan informasi yang diperoleh sebelumnya agar menjadi lebih jelas untuk mendukung terjadinya proses knowledge sharing (Santos et al., 2012). Sebagai contoh, penggunaan media teknologi seperti pengunaan internet atau pun media lainnya akan membantu individu menemukan kejelasan suatu informasi yang dibutuhkan. Namun, adanya penggunaan teknologi dapat menjadi hambatan terjadinya proses knowledge sharing, karena turunnya komunikasi yang terjadi secara formal dan juga mengakibatkan adanya ketergantungan dalam penggunaan teknologi (Reige, 2005).

\section{METODE PENELITIAN}

Jenis penelitian ini adalah analisis kualitatif yang digunakan untuk menjelaskan dan memahami fenomena tentang apa yang dialami oleh subyek penelitian. Penelitian ini dilakukan dengan menggunakan proses observasi dan wawancara untuk mendapatkan data. Observasi ditujukan untuk melihat seberapa besar persentase mahasiswa dalam kegiatan diskusi di dalam kelas. Obyek dari penelitian ini adalah mahasiswa Program Studi Manajemen Fakultas Ekonomika dan Bisnis, Universitas Kristen Satya Wacana. Penelitian ini menggunakan sumber data primer melalui wawancara langsung kepada mahasiswa yang telah ditunjuk dan rekomendasi oleh para dosen pengajar. Penelitian ini diharapkan mampu menjawab permasalahan dalam penelitian ini.

\section{a. Teknik Pengumpulan Data}

Data primer diperoleh dari proses wawancara yang dilakukan untuk mendapatkan informasi terkait faktor apa yang menghambat mahasiswa untuk berpartisipasi dalam proses diskusi. Wawancara dilakukan dengan pembicaraan informal dan bergantung pada spontanitas pengajuan pertanyaan. Hasil wawancara disimpan dengan menggunakan perekam suara dan kemudian ditulis kembali sebagai sumber data untuk dianalisis.

\section{b. Tahapan Penelitian}

Pada penelitian ini, tahapan penelitian dimulai dengan beberapa tahapan sebelum penarikan kesimpulan dilakukan. Tahapan tersebut sebagai berikut:

1. Observasi

Peneliti mengamati secara penuh dengan bebas untuk mengetahui proses belajar mengajar secara langsung. Hal ini dilakukan untuk mendapatkan data dan informasi akan fenomena yang diamati pada penelitian ini.

2. Pemilihan Responden

Peneliti menentukan responden yang akan diwawancarai dengan mengambil beberapa mahasiswa dari setiap kelas yang telah diobservasi. Responden yang diambil juga merupakan rekomendasi yang diberikan dari 
dosen pengajar di dalam kelas untuk diwawancarai. Pemilihan berakhir jika sudah terjadi pengulangan pada informasi yang diperlukan dan sudah didapatkan, maka pemilihan responden dapat diakhiri. Jadi, apabila sudah mulai terjadi pengulangan informasi maka pemilihan responden dapat dihentikan (Moleong, 2010).

3. Proses Pengambilan Data

Pengambilan data dilakukan setelah pemilihan responden. Teknik wawancara digunakan untuk mengambil data dari responden yang terpilih. Data dari responden tersebut dikumpukan sebagai sumber informasi dalam penelitian ini.

4. Reduksi Data

Tahap ini dilakukan untuk mengidentifikasi data yang memiliki makna dan berkaitan dengan fokus dan masalah penelitian. Langkah selanjutnya, data tersebut kemudian diberi kode agar mudah ditelusuri asal sumbernya.

5. Kategorisasi

Kategorisasi adalah upaya memilah data ke dalam bagian yang memiliki kesamaan. Dalam proses ini, data yang sama dipilah sesuai dengan tema yang berkaitan dengan permasalahan penelitian.

6. Analisis Data

Dari hasil data yang sudah dipilah berdasarkan temanya, langkah selanjutnya adalah analisis data. Langkah ini dilakukan untuk menganalisis dan menginterpretasikan data berdasarkan referensi dan teori yang ada. Hal ini dilakukan untuk menarik kesimpulan yang akan menjawab permasalahan dalam penelitian ini.

7. Penarikan Kesimpulan

Penarikan kesimpulan dilakukan untuk memberikan jawaban pada permasalahan penelitian ini, setelah dilakukan pembahasan pada data yang telah diinterpretasikan berdasarkan tema pada topik penelitian. Kesimpulan diharapkan mampu menjawab persoalan penelitian untuk menemukan faktor apa yang menjadi hambatan pada proses diskusi di dalam pembelajaran di kelas (Moleong, 2010).

\section{HASIL PENELITIAN}

\section{a. Profil Penelitian}

Obyek penelitian ini adalah mahasiswa yang mengambil matakuliah MK1, MK2, MK3, MK4, dan MK5 yaitu matakuliah yang wajib diambil bagi mahasiswa Program Studi Manajemen Fakultas Ekonomika \& Bisnis, Universitas Kristen Satya Wacana. Matakuliah tersebut dipilih karena dalam proses belajar mengajarnya memungkinkan dilakukannya proses diskusi kelas. Selain proses belajar mengajarnya, kelas tersebut memungkinkan adanya kesempatan bagi mahasiswa untuk berpartisipasi dalam proses diskusi. Observasi awal dilakukan untuk mengamati tingkat partisipasi mahasiswa dalam proses diskusi di kelas. Selama observasi, peneliti melakukan pencatatan pada segala kegiatan dalam proses diskusi di kelas dan melihat seberapa sering kesempatan untuk berdiskusi di kelas diberikan. Selama proses diskusi di kelas, peneliti mencatat aktivitas mahasiswa dalam bertanya dan berpendapat di kelas. Dari hasil observasi ini, peneliti menemukan tingkat partisipasi mahasiswa dalam proses diskusi yang dapat dilihat di Tabel 1 berikut ini. 
Tabel 1. Hasil Observasi

\begin{tabular}{|c|c|c|c|c|c|c|}
\hline \multirow{2}{*}{ No } & \multirow{2}{*}{ Pembahasan Observasi } & \multicolumn{5}{|c|}{ Matakuliah Observasi } \\
\hline & & MK 1 & MK2 & MK3 & MK4 & MK5 \\
\hline 1 & Mahasiswa yang hadir saat observasi & 48 & 50 & 57 & 34 & 57 \\
\hline 2 & Total kesempatan untuk berdiskusi & $3 x$ & $5 x$ & $7 x$ & $6 x$ & $3 x$ \\
\hline 3 & $\begin{array}{l}\text { Total mahasiswa yang ikut dalam } \\
\text { partisipasi diskusi }\end{array}$ & 1 & 5 & 6 & 6 & 15 \\
\hline 4 & $\begin{array}{l}\text { Persentase keaktifan mahasiswa dalam } \\
\text { berdiskusi }\end{array}$ & $2.08 \%$ & $10 \%$ & $7 \%$ & $17.6 \%$ & $26.3 \%$ \\
\hline
\end{tabular}

Sumber: Data olahan (2017).

Tabel 1 memperlihatkan seberapa besar partisipasi mahasiswa dalam proses diskusi. Hasil observasi memperlihatkan persentase partisipasi mahasiswa dalam proses diskusi dan kesempatan yang diberikan untuk berpartisipasi pada mahasiswa di kelas. Hasil tersebut menunjukkan kemungkinan adanya hambatan yang terjadi dalam proses diskusi di kelas, sehingga partisipasi mahasiswa dalam proses diskusi rendah.

\section{b. Hasil Penelitian}

Berdasarkan hasil wawancara yang dilakukan oleh sejumlah mahasiswa yang menjadi narasumber dalam penelitian ini, hasil penelitian ini menemukan sejumlah faktor yang menjadi barriers dalam partisipasi mahasiswa dalam berdiskusi di kelas. Sejumlah barriers yang ditemukan dapat dikelompokkan menjadi dua, yaitu barrier yang berasal dari dalam individu dan yang berasal dari luar individu.

\section{Faktor individu sebagai barriers dalam proses diskusi}

Dalam penelitian ini faktor individu dapat menjadi hambatan keterlibatan mahasiswa dalam proses diskusi di kelas. Hal tersebut dapat dibuktikan berdasarkan hasil penelitian berikut :

\section{Faktor kognitif}

Barriers yang ditemukan dalam penelitian ini, yang pertama adalah faktor kognitif yaitu bagaimana mahasiswa memahami informasi atau pengetahuan yang diterima pada saat proses belajar mengajar, seperti mahasiswa memahami atau tidak terhadap materi yang disampaikan. Faktor kognitif tersebut berpotensi menghambat terjadinya proses diskusi sebagai bentuk share of knowledge. Hasil wawancara yang diperoleh menunjukkan bagaimana mahasiswa memahami atau tidaknya informasi dan pengetahuan yang diterima menjadi salah satu rintangan bagi individu untuk terlibat dalam proses diskusi. Hal tersebut dicerminkan dari hasil wawancara sebagai berikut:

Kalo dari materi sendiri nggak nangkep sih mas apa yang dijelasin gitu, jadi mau ngutarain apa, mau nanya apa, mau ngomong apa juga bingung - A5.

Saya nggak paham materinya apa, jadinya saya juga mau ngomong apa ya nggak tau gitu apa yang mau diomongin - A4.

Berdasarkan hasil wawancara di atas dapat dipahami bahwa proses memahami dalam diri mahasiswa akan informasi yang diterima selama proses belajar mengajar menjadi rintangan tersendiri bagi mahasiswa untuk terlibat dalam 
proses diskusi, sehingga terjadi barriers untuk berbagi pengetahuan dan mengembangkan pengetahuan bersama.

\section{Faktor kemampuan komunikasi}

Faktor komunikasi juga menjadi barrier dalam penelitian ini yang membuat partisipasi mahasiswa dalam proses diskusi kurang. Misalnya, bagaimana mahasiswa mengkomunikasikan informasi yang dimiliki. Kemampuan komunikasi sangat berguna untuk membagikan informasi dan pengetahuan kepada orang lain. Hasil wawancara yang diperoleh menunjukkan bagaimana kemampuan komunikasi mahasiswa menjadi hambatan dalam proses diskusi. Hal ini dapat tercermin pada hasil wawancara berikut:

Mau ngungkapin dengan kata-kata gitu sulitlah, terus kan kadang pikirannya sebenernya udah kebayang-bayang mau ngomong apa,.. tapi susah gitu mau ngomongnya-A1.

Sepertinya susah berkata-kata gitu, kalo mau nanya kayak susah mau ngomongnya $-A 7$.

Hasil wawancara di atas menunjukkan bagaimana mahasiswa memiliki kesulitan dalam menyampaikan pendapatnya. Kesulitan mahasiswa dalam menyampaikan pendapat mencerminkan kemampuan komunikasi yang dimiliki mahasiswa rendah. Hal tersebut menunjukkan adanya kemungkinan hambatan yang terjadi karena faktor kemampuan komunikasi yang dimiliki mahasiswa untuk berdiskusi di kelas.

\section{Adanya risiko}

Faktor lain yang menjadi barrier dalam proses diskusi yang ditemukan adalah adanya risiko yang dirasakan oleh individu. Adanya risiko yang mungkin akan dihadapi dalam menyampaikan pendapat menjadi barriers dalam proses berdiskusi pada mahasiswa. Data yang diperoleh dari hasil wawancara menunjukkan adanya risiko yang dihadapi mahasiswa dalam partisipasinya pada proses diskusi. Hal tersebut tercermin dari hasil wawancara berikut:

Ketika aku Tanya, tapi dosennya itu seperti menyoroti ke yang tanya gitu, jadi aku merasa kayak terintimidasi gitu. Jadi takut, karena takut dibilang sok pinter gitu, terus dulu pernah ada pengalaman jadi takut lagi kalo terjadi kayak gitu-A3.

Takutnya nanti salah, kalo nanti salah gitu takutnya nanti malah diejek temen gitu - Al0.

Saya takut salah, karena saya takut nanti kalo salah diliatin terus diomongin di luar gitu terus digosipin - A15.

Dari data tersebut, mahasiswa merasakan adanya risiko yang harus dihadapi saat terlibat dalam proses diskusi untuk menyampaikan pendapatnya. Risiko yang dihadapi mahasiswa, seperti adanya intimidasi dan takut terjadi kesalahan dalam meyampaikan informasi mencerminkan adanya risiko ketika terlibat dalam proses diskusi. Adanya risiko tersebut menjadi hambatan bagi mahasiswa untuk terlibat dalam proses diskusi.

\section{Faktor motivasi}

Salah satu hambatan lain dalam proses diskusi, yaitu kurangnya motivasi pada individu untuk ikut berpartisipasi dalam proses diskusi. Ada atau tidaknya motivasi dapat mempengaruhi mahasiswa untuk terlibat dalam proses diskusi. Pada hasil wawancara yang didapatkan menggambarkan pengaruh motivasi yang ada pada mahasiswa menentukan apakah mahasiswa tersebut tertarik 
untuk terlibat dalam proses diskusi atau tidak. Hal tersebut tercermin pada hasil wawancara berikut:

Pada dasarnya aku orangnya males gitu, cuek jadi bikin saya males gitu. Sebenernya saya masuk kelas nggak ada niatan gitu (mengajukan pendapat atau diskusi), karena saya masuk cuman tanda tangan, absen, dapet ilmu udah gitu aja - A5.

Kadang aku bingung mau nanya apa, karena kadang kan bosen dengerin materi jadi nggak bisa nanya - A12.

Saya orangnya malesan jadi nggak ngikutin, kurang tertarik dengan materinya. Dari akunya sendiri emang nggak pingin tau dan di kelas orangnya juga pendiem, lebih suka diem aja di kelas terus main HPA16.

Dari hasil wawancara di atas, mahasiswa tidak memiliki ketertarikan akan menerima informasi berupa materi di kelas. Motivasi dalam menerima informasi yang disampaikan akan mempengaruhi mahasiswa dalam ketertarikannya untuk terlibat dalam proses diskusi. Motivasi yang kurang kuat untuk belajar membuat mahasiswa tidak tertarik untuk menerima informasi yang diberikan. Hal tersebut mencermikan bahwa motivasi pada mahasiswa dapat menjadi hambatan terjadinya proses diskusi di kelas.

\section{Faktor kepercayaan diri}

Hambatan lainnya pada proses diskusi adalah kepercayaan diri pada individu untuk menyampaikan informasi atau pengetahuan yang dimiliki. Perlu adanya keberanian untuk mengungkapkan pendapat kepada orang lain yang memiliki pemikiran yang mungkin berbeda. Keberanian untuk menerima dan mengabaikan risiko pada individu bergantung bagaimana individu tersebut percaya akan kemampuan yang dimiliki. Namun, hasil wawancara mencerminkan kemampuan individu yang berbeda dalam menerima risiko maupun menghadapinya dapat menjadi hambatan dalam proses diskusi. Hal tersebut tercermin pada hasil wawancara sebagai berikut:

Kalo nanya diliatin sama temen-temen sekelas gitu jadi belum PD masih malu - A7.

Karena saya orangnya memang menutup diri gitulah, pemalu gitu A5.

Sebenernya ada yang mau ditanya cuman malu - A10.

Hasil wawancara di atas menunjukkan bahwa kepercayaan diri mempengaruhi mahasiswa untuk menyampaikan pendapatnya atau pun bertanya. Kepercayaan diri mahasiswa yang mempengaruhi kemampuannya untuk berani menyampaikan pendapat dapat menjadi hambatan bagi individu tersebut untuk mau terlibat dalam proses diskusi. Selain itu, rasa malu dan sifat pasif pada mahasiswa membuat kepercayaan diri pada mahasiswa menurun. Hal tersebut mencerminkan bahwa kepercayaan diri yang rendah pada mahasiswa dapat menjadi hambatan pada keterlibatannya dalam proses diskusi.

\section{Faktor nilai dan budaya}

Faktor nilai dan budaya yang tertanam pada individu mempengaruhi tindakan yang akan dilakukan individu sehari-hari, bahkan di dalam kegiatan belajar mengajar. Nilai dan budaya pada individu, seperti menghormati orang yang lebih tua, etika berbicara, status social, dan sebagainya dapat mempengaruhi individu dalam keterlibatannya pada proses diskusi. Pengaruh nilai dan budaya 
tersebut dapat menjadi hambatan bagi mahasiswa, karena adanya faktor ini membuat individu kurang berani untuk menyampaikan pendapatnya. Pada hasil wawancara ditemukan bahwa individu merasa sungkan untuk menyampaikan informasi atau penngetahuannya kepada orang yang lebih berpengalaman. Hal tersebut mencerminkan adanya nilai dan budaya pada individu yang menjadi hambatan pada proses diskusi. Adanya faktor nilai dan budaya dapat dilihat dari hasil wawancara berikut:

Kebiasaan sih mas, kalo ke guru itu ya kalo mau bicara sungkan gitu, modelnya kan sama kalo ke orang tua gitu, sungkanlah-A1.

Aku sungkanlah ke dosen, masa dosen jelasin ini terus aku potong 'bu mau tanya', secara etika kan nggak baik gitu. Juga dosen otomatis status pendidikannya lebih tinggi dari saya, umurnya juga lebih tua dari saya, masa iya saya motong gitu aja $-A 2$.

Dari hasil wawancara di atas dapat dipahami bahwa pemahaman akan nilai untuk menghormati orang yang lebih tua dapat mendorong mahasiswa untuk menahan diri dalam mengajukan pertanyaan atau pendapatnya. Adanya rasa menghargai dan pemahaman etika pada individu, sehingga menahan keinginan individu untuk berpendapat mencerminkan adanya faktor nilai dan budaya yang terjadi dalam proses diskusi. Hal tersebut juga menjadi hambatan pada proses diskusi, karena nilai yang dipahami tersebut membuat mahasiswa menahan diri untuk terlibat dalam proses diskusi di kelas.

\section{Faktor organisasional sebagai barriers dalam proses knowledge sharing}

Faktor organisasional merupakan faktor di luar individu yang menjadi hambatan bagi individu untuk berpartisipasi dalam proses diskusi. Struktur organisasional memiliki peran untuk memfasilitasi kegiatan diskusi atau pertukaran informasi, tetapi penelitian ini menunjukkan adanya barriers pada faktor organisasional yang membuat mahasiswa sulit melakukan proses diskusi. Hal tersebut dapat dilihat dari hasil penelitian berikut:

\section{Faktor kesempatan untuk berpartisipasi dalam diskusi}

Faktor kesempatan yang diberikan akan mempengaruhi individu dalam kesempatannya untuk menyampaikan pendapat. Kesempatan yang diberikan seperti kesempatan untuk bertanya atau pun mengajukan pendapat. Namun, Tabel 1 pada hasil observasi menunjukkan kurangnya kesempatan yang diberikan untuk berdiskusi. Kesempatan tersebut juga dapat berupa kurangnya waktu untuk berdiskusi, sehingga membuat mahasiswa tidak memiliki banyak kesempatan untuk mengutarakan pendapatnya. Dari hasil wawancara yang dilakukan mencerminkan bahwa kesempatan dapat menjadi hambatan terjadinya proses diskusi di kelas. Hal tersebut dapat dicerminkan melalui hasil wawancara sebagai berikut:

Kalo mau mengajukan pendapat gitu tergantung dosennya apakah memberi kesempatan atau tidak gitu. Kalo dosen saya ini kurang begitu ngasih kesempatan untuk berpendapat gitu - A2.

Kadang, sering saya mau tanya tapi keduluan ada yang tanya lainnya dan pertanyaannya itu sama, itu sering kejadian - A3.

Waktunya itu cepet gitu jadi kadang dosennya itu ya ngomong terus sampe akhir gitu - A6. 
Dari hasil wawancara di atas, mahasiswa menganggap kesempatan untuk berpendapat atau berdiskusi kurang diberikan kepada mahasiswa oleh dosen, sehingga mahasiswa menjadi terbatas untuk mengutarakan apa yang mereka ingin sampaikan. Selain itu, dari Tabel 1 hasil observasi menunjukkan jumlah mahasiswa yang lebih banyak daripada kesempatan yang diberikan membuat mahasiswa harus cepat memanfaatkan setiap kesempatan yang diberikan. Kurangnya waktu yang diberikan akan memperkecil kesempatan kepada mahasiswa untuk berpendapat atau pun menanyakan kejelasan informasi yang mereka terima. Kurangnya waktu tersebut mencerminkan adanya hambatan pada kesempatan yang diberikan pada mahasiswa untuk berdiskusi.

\section{Faktor penghargaan}

Selain kurangnya kesempatan dan waktu yang ada, penghargaan yang diberikan kepada partisipan diskusi dapat menjadi hambatan ketika proses diskusi terjadi. Adanya penghargaan menjadi penting karena mempengaruhi motivasi individu untuk mau berpartisipasi dalam proses diskusi yang terjadi. Dari hasil wawancara menunjukkan bahwa kurangnya penghargaan membuat mahasiswa tidak tertarik untuk berpartisipasi dalam proses diskusi karena menganggap tidak adanya keuntungan yang didapatkan. Hal tersebut dapat dicerminkan melalui hasil wawancara berikut:

Asal ada yang mau menerima apa yang aku terima - Al.

Saya pikirnya sia-sia ngasih masukan, mungkin karena materinya udah dari dulu memang seperti itu. Juga dosen kan seperti atasan, jadi kan percuma, paling kan gak didengerin atau tidak diresponA11.

Hasil wawancara di atas menunjukkan bahwa mahasiswa tertarik untuk berdiskusi, tetapi kurangnya tingkat partisipan yang ingin terlibat untuk berdiskusi membuat proses diskusi menjadi terhambat. Kurang adanya penerimaan dari orang lain tentang apa yang ingin disampaikan oleh mahasiswa akan membuat mahasiswa tersebut merasa tidak dihargai dan merasa lebih baik tidak mengutarakan pemikirannya. Hal tersebut menjadi cerminan bahwa faktor penghargaan dapat menjadi hambatan pada proses diskusi di kelas.

\section{Faktor lingkungan}

Faktor lingkungan yang ditemukan dalam penelitian ini menjadi hambatan dalam proses diskusi karena rasa ketidaknyaman di dalam kelas membuat mahasiswa tidak tertarik untuk terlibat dalam proses diskusi atau pun mengajukan pendapatnya. Ketidaknyamanan dalam berinteraksi pada orang lain juga mencerminkan adanya hambatan yang terjadi pada faktor lingkungan. Ketidaknyamanan pada suasana di dalam kelas juga menjadi hambatan bagi mahasiswa untuk berdiskusi. Hal tersebut dapat dicerminkan dari hasil wawancara berikut:

Aku sendiri sih kurang fleksibel gitu kurang nyaman sama kelasnya, juga dosennya kurang memperhatikan mahasiswanya gitu jadi ya gak fleksibel aja buat kayak ada diskusi atau mau tanya sesuatu gitu - A4. Kadang presentasinya bosenin jadi males untuk didengerin, jadi kayak 'aduh tadi bahas apa ya?' jadi nggak ngerti materinya jadi males mau nanya-A10. 
Ada beberapa orang yang kayak ada gap gitu dengan beberapa orang temen di kelas, jadi risih gitu kalo mau nanya mendadak males gitu mau nanya. Merasa terintimidasi karna dia, kayak adanya dia itu mengintimidasi gitu - A12.

Menurutku kelas ini kurang kooperatif gitu kan ya, kalo untuk kayak komunikasinya itu kurang gitu, karna kan ada yang berisik sendiri ada yang diem dan kebanyakan kita alami saat presentasi di depan, orang-orang itu nggak memperhatikan kita gitu jadi tuh jarang yang memperhatikan secara sukarela gitu - A13.

Dari hasil wawancara di atas dapat dipahami bahwa mahasiswa kurang merasa nyaman pada proses penyampaian infomasi dan pengetahuan berupa materi membuat mahasiswa merasa tidak tertarik untuk mengajukan pendapatnya. Ketidaktertarikan akan materi yang diterima pada hasil wawancara tersebut membuat mahasiswa kurang memahami infomasi dan pengetahuan yang disampaikan, sehingga mahasiswa menjadi terhambat untuk berdiskusi di kelas. Adanya pengaruh lingkungan sosial pada mahasiswa yang kurang baik menyebabkan ketidaknyamanan mahasiswa untuk menyampaikan pendapatnya di dalam kelas. Ketidaknyamanan yang dirasakan mahasiswa tersebut tentunya menjadi hambatan terjadinya proses diskusi di kelas.

\section{PEMBAHASAN}

Penelitian yang dilakukan pada mahasiswa Program Studi Manajemen menunjukkan adanya faktor-faktor yang menghambat terjadinya proses diskusi di dalam kelas. Seperti, kemampuan kognitif pada individu yang mempengaruhi individu tersebut dalam memahami informasi dan pengetahuan yang didapatkan. Pengaruh kemampuan kognitif ini menentukan seberapa banyak informasi yang ia miliki untuk kemudian dikembangkan atau pun dibagikan kembali. Kemampuan individu yang kurang baik dalam memahami informasi dan pengetahuan yang disampaikan dapat menjadi rintangan bagi individu untuk terlibat dalam proses share of knowledge. Hal ini sejalan dengan Bures (2003) yang menyatakan bahwa kurangnya informasi yang dimiliki individu dapat membuatnya menahan diri untuk terlibat dalam proses share of knowledge yang ada, sehingga dapat dipahami bahwa tingkat kemampuan kognitif yang dimiliki individu dapat menjadi barriers dalam share of knowledge.

Kemampuan komunikasi menjadi salah satu faktor yang mempengaruhi keterlibatan individu dalam proses share of knowledge. Kemampuan komunikasi untuk menyampaikan ide, gagasan, atau pendapat dan pengetahuan yang dimiliki mempengaruhi individu dalam partisipasinya pada proses knowledge sharing yang terjadi. Temuan ini sejalan dengan Reige (2005) bahwa komunikasi yang efektif merupakan dasar penunjang terjadinya kegiatan knowledge sharing yang lebih efektif. Hal ini menunjukkan bahwa kemampuan komunikasi sangat dibutuhkan bagi individu untuk dapat menyampaikan informasi dan pengetahuannya dengan baik, sehingga perlu disadari bahwa kemampuan komunikasi yang kurang baik dapat menjadi hambatan tersendiri bagi individu untuk terlibat dalam proses share of knowledge.

Adanya risiko yang mungkin dialami oleh individu ketika terlibat dalam proses knowledge sharing dapat menjadi hambatan bagi individu untuk mau terlibat dalam proses knowlede sharing. Risiko seperti adanya intimidasi, takut 
adanya kesalahan dalam penyampaian informasi, dan takut akan dikucilkan orang lain membuat individu menahan diri untuk terlibat dalam proses share of knowledge. Hal ini sejalan dengan hasil penelitian Chmielecki (2013) yang menemukan bahwa individu merasa takut untuk berpartisipasi dalam proses knowledge sharing karena mungkin akan terjadi kesalahan pada saat menyampaikan informasi atau pengetahuan yang akan membuat individu tersebut merasa malu. Adanya risiko yang dirasakan atau pun dialami oleh individu memungkinkannya untuk menahan dirinya dalam partisipasi pada proses knowledge sharing.

Faktor motivasi pada individu mempengaruhi keinginannya untuk terlibat dalam proses knowledge sharing yang terjadi. Motivasi pada individu untuk mendapatkan informasi atau pengetahuan maupun membagikannya berpengaruh pada terjadinya proses share of knowledge. Keinginan individu untuk menemukan kejelasan akan informasi yang dimiliki juga mempengaruhi motivasi individu untuk mau terlibat dalam proses knowledge sharing. Selain itu, kesadaran pada individu akan keuntungan yang diperoleh pada keterlibatannya dalam proses diskusi membuat individu menjadi lebih termotivasi untuk mengembangkan pengetahuannya melalui kegiatan knowledge sharing. Sejalan dengan Parker dan Hess (2000) yang menyatakan bahwa kesadaran pada individu akan keuntungan yang didapat dalam proses knowledge sharing dapat mendukung pengembangan informasi dan peningkatan pengetahuan individu tersebut. Namun, kurangnya kesadaran akan keuntungan tersebut dapat menjadi hambatan pada proses knowledge sharing, karena individu tidak termotivasi untuk terlibat di dalamnya. Sejalan dengan Disterer (2001) yang menyebutkan bahwa proses penyampaian informasi dalam proses knowledge sharing akan terhambat karena individu tidak menyadari adanya keuntungan yang didapat dalam keterlibatannya pada proses tersebut. Hal ini menjelaskan bahwa motivasi pada individu mampu mempengaruhi keterlibatan individu dalam partisipasinya dalam proses knowledge sharing.

Kepercayaan diri pada mahasiswa dapat menjadi pengaruh bagi individu untuk dapat terlibat dalam proses sharing of knowledge. Individu membutuhkan keberanian untuk dapat menyampaikan pendapat, ide, atau gagasan yang dimilikinya kepada orang lain. Kepercayaan diri pada individu mempengaruhi keberaniannya untuk mau terlibat dalam proses knowledge sharing yang ada. Namun, Wang dan Noe (2009) menemukan bahwa kepercayaan diri pada individu kurang dapat menurunkan keberaniannya untuk terlibat dalam proses share of knowledge. Dari hal tersebut dapat dipahami bahwa kepercayaan diri sangat berpengaruh pada keberanian individu untuk berpartisipasi dalam proses share of knowledge. Kepercayaan diri pada kemampuannya untuk menyampaikan informasi akan berdampak pada keterlibatannya dalam proses share of knowledge.

Nilai dan budaya yang tertanam pada individu juga mempengaruhi individu untuk mengambil keputusan dan tindakan yang akan dilakukannya seperti keputusannya untuk terlibat dalam proses knowledge sharing atau tidak. Adanya nilai-nilai, seperti etika berbicara, menghormati maupun menghargai orang yang lebih tua akan menjadi pertimbangan individu untuk berpendapat. Individu berusaha untuk tidak menyimpang dari nilai dan budaya yang tertanam pada dirinya dengan menahan diri untuk tidak menyampaikan gagasannya. Dari hal tersebut dapat dipahami bahwa nilai dan budaya yang ada mempengaruhi individu 
untuk mau atau tidaknya dalam menyampaikan pendapat, ide, atau gagasannya kepada orang lain. Hal ini sejalan dengan DeLong dan Fahey (2000) yang menyatakan bahwa nilai dan budaya pada individu berpengaruh pada tindakannya untuk terlibat dalam proses share of knowledge, sehingga dapat dipahami bahwa nilai dan budaya yang ada dapat menjadi rintangan bagi individu untuk dapat terlibat dalam proses share of knowledge.

Kesempatan yang diberikan bagi individu untuk berdiskusi juga dapat mempengaruhi terjadi atau tidaknya proses knowledge sharing. Kesempatan yang dimaksudkan seperti kesempatan untuk menyampaikan pendapat, ide, atau gagasan maupun untuk mengajukan pertanyaan. Selain itu, waktu yang diberikan kepada individu untuk menyampaikan informasi dan pengetahuannya mencerminkan adanya kesempatan untuk berpartisipasi dalam proses knowledge sharing, sehingga dapat dipahami jika tidak adanya kesempatan yang diberikan pada individu untuk menyampaikan pendapatnya, maka proses share of knowledge akan terhambat. Sejalan dengan Rosen et al.,(2007) dan Santos et al.,(2012) yang menyatakan bahwa keterbatasan waktu dan kurangnya kesempatan yang diberikan untuk menyampaikan informasi membuat proses knowledge sharing menjadi terhambat. Dari hal tersebut dapat dipahami bahwa adanya kesempatan mempengaruhi terjadinya proses knowledge sharing.

Adanya penghargaan yang diberikan menjadi pertimbangan bagi individu pada keterlibatannya di dalam proses share of knowledge. Penghargaan seperti penerimaan orang lain pada informasi yang disampaikan individu dan juga adanya pemberian apresiasi bagi individu yang terlibat dalam proses knowledge sharing, dapat menimbulkan ketertarikan individu pada keterlibatanya untuk berpartisipasi dalam proses knowledge sharing. Sistem penghargaan terstruktur dengan baik dan pemberian penghargaan yang terus menerus dilakukan pada partisipan yang terlibat pada proses knowledge sharing akan mendorong individu untuk terus berpartisipasi dalam menyampaikan pendapat, ide, dan gagasannya. Sejalan dengan Riege (2005), sistem pengharggan yang baik akan mendukung terciptanya kebiasaan individu untuk terus berpartisipasi dalam proses knowledge sharing. Perlu dipahami bahwa adanya penghargaan yang diberikan akan mempengaruhi keterlibatan individu pada proses share of knowledge.

Faktor lingkungan dapat mempengaruhi proses knowledge sharing pada individu. Kenyamanan individu akan suasana di suatu tempat mencerminkan adanya faktor lingkungan yang mempengaruhi individu. Adanya kenyamanan dalam menyampaikan informasi maupun menerima pengetahuan yang disampaikan akan mempengaruhi individu untuk mau terus mengembangkan pengetahuannya. Individu akan lebih tertarik untuk terlibat dalam proses share of knowledge, karena individu merasa nyaman untuk menerima informasi maupun menyampaikan pengetahuan yang dimiliki. Hal ini sejalan dengan Reige (2005), faktor lingkungan yang baik dapat mempengaruhi individu untuk mau berpartisipasi dalam proses knowledge sharing, sehingga dapat disadari perlu adanya lingkungan nyaman yang diciptakan bagi individu untuk berpartisipasi dalam proses diskusi. Hal tersebut dapat menjadi hambatan tersendiri bagi individu untuk terlibat dalam proses knowledge sharing, karena individu merasa tidak nyaman untuk menerima informasi ataupun menyampaikan pengetahuan yang dimilikinya. 


\section{PENUTUP}

\section{a. Kesimpulan}

Berdasarkan hasil penelitian yang ada dapat dipahami bahwa terdapat hambatan yang berasal dari faktor individu dan organisational dalam proses diskusi mahasiswa yang terjadi pada proses belajar mengajar di kelas. Faktor yang menghambat mahasiswa dalam proses diskusi membuat kegiatan sharing of knowledge pada individu menjadi rendah. Hambatan yang terjadi pada faktor individu yang menghambat terjadinya proses diskusi di dalam proses belajar mengajar adalah kemampuan kognitif, kemampuan komunikasi, risiko yang akan dihadapi, motivasi yang rendah, kurangnya kepercayaan diri, dan nilai budaya pada individu. Faktor-faktor tersebut merupakan hambatan pada individu yang ditemukan pada mahasiswa berdasarkan hasil yang ditemukan peneliti.

Hambatan yang terjadi pada faktor organisational merupakan hambatan di luar individu yang menjadi barriers terjadinya proses diskusi pada mahasiswa. Hambatan-hambatan tersebut berupa kesempatan untuk berdiskusi di dalam kelas, sistem penghargaan yang ada, dan lingkungan di sekitar individu. Hal tersebut menjadi hambatan terjadinya proses sharing of knowledge pada individu.

\section{b. Implikasi}

\section{1) Implikasi Teoritis}

Penelitian ini menemukan adanya hambatan yang terjadi dalam share of knowledge dalam kegiatan diskusi di kelas. Adanya rintangan pada individu untuk terlibat dalam proses share of knowledge tidak hanya terjadi pada konteks individu dalam sebuah perusahaan dengan perbedaan jenjang hierarki yang ada, tetapi juga ditemukan dalam konteks keterlibatan mahasiswa dalam proses diskusi di kelas. Temuan ini dapat memperkuat temuan-temuan sebelumnya, yaitu adanya barriers dalam share of knowledge dalam konteks yang berbeda.

\section{2) Implikasi Terapan}

Implikasi terapan berdasarkan hasil penelitian ini di antaranya adalah pentingnya untuk meningkatkan motivasi individu agar tertarik dan mempunyai kebutuhan terhadap informasi dan pengetahuan bagi pengembangan diri ke depan. Implikasi lain adalah dengan memberikan kesempatan dan apresiasi yang lebih bagi mahasiswa untuk menyampaikan pengetahuan yang dimilikinya. Dengan demikian, kebutuhan pengembangan strategi pembelajaran yang lebih inovatif diperlukan agar dapat meningkatkan partisipasi individu dalam proses share of knowledge di kelas.

\section{DAFTAR REFERENSI}

Andolsek, D.M., Andolsek, S. \& Poljane, G. (2015). Knowledge Sharing in an Organization from the Perspective of the Individual. International Journal of Cognitive Research in Science, Vol 3. No. 2. Engineering and Education (IJCRSEE). 
Barson, R.J., Foster, G., Struck, T., Ratchev, S., Pawar, K., Weber, F., \& Wunram, M.. Inter-and Intra-Organisational Barriers to Sharing Knowledge in the Extended Supply-Chain. Conference Proceedings.

Bartol, Kathyrn M., \& Srivastava, A. (2002). Encouraging Knowledge Sharing: The Role of Organizational Reward Systems. Journal of Leadership and Organization Studies, Vol 9. No. 1.

Buckley, S. (2012). Higher Education and Knowledge Sharing: From Ivory Tower to Twenty-first Century. Innovations in Education and Teaching international, Vol. 49. No. 3 (Agustus): 333-344. School of Computing University of South Africa.

Bures, V. (2003). Cultural Barriers in Knowledge Sharing. Economics and Management, Vol 6., Special issue, pp. 57-62. Liberec.

Chmielecki, M. (2013). Knowledge Sharing Among Faculties - Qualitative Research Findings From Polish Universities. International Journal of Contemporary Management, Vol 12(3), pp. 93-102.

Cabrera, A., \& Cabrera, E.F. (2002). Knowledge-sharing Dilemmas. Organization Studies. Vol 23, No. 5, pp. 687-710.

De Long, D.W. \& Fahey, L. (2000). Diagnosing Cultural Barriers to Knowledge Management. Academy of Management Executive, Vol 14. No.4.

Disterer, G. (2001). Individual and Social Barriers to Knowledge Transfer. Proceedings of the $34^{\text {th }}$ Hawaii International Conference on System Sciences. University of Applied Sciences.

Flaxton, T. (2013). Knowledge Exchange as a Practice. Journal of Media Practice, Vol 14, No. 3, pp, 211-229.

Gider, O., Ocak, S. \& Top, M. (2015). Perceptions of Physicians about Knowledge Sharing Barriers in Turkish Health Care System. J Med Syst 39: 42. Education \& Training.

Hansen, M.T., Nohria, N. \& Terney, T. (1999). What's Your Strategy for Managing Knowledge? Harvard Business Review.

Huges, R.L., Ginnet, R.C. \& Curphy, G.J. (2015). Leadership: Enchancing the Lesson of Experience. Singapore: McGraw-Hill Education, Inc.

Kharabsheh, R.A. (2007). A Model of Antecendents of Knowledge Sharing. The Electronico Journal of Knowledge Management, Vol 5, Issue 4, pp. 419426. Available at www.ejkm.com.

Liu, C.C., Lin, C.C., Chang, C.Y., \& Chao, P.Y. (2014). Knowledge Sharing among University Students Facilitated with a Creative Commons Licensing Mechanism: A Case Study in a Programing Course. Educational Technology \& Society, Vol 17(3), pp. 154-167.

Lee, J.N. (2000). The Impact of Knowledge Sharing, Organizational Capability and Partnership Quality on IS Outsourcing Success. Information \& Management, Vol 38, pp. 323-335. 
Li, Wei. (2009). Virtual Knowledge Sharing in a Cross-cultural Context. Journal of Knowledge Management, Vol 14, No. 1, pp. 38-50.

Mbaso, T.G. (2005). Laveraging Knowledge Management as the Basis to Achieve a Sustainable Competitive Advantage in KwaZulu-Natal Legislature. Stellenbosch University. Available at http://scholar.sun.ac.za.

Moleong, L.J. (2010). Metodologi Penelitian Kualitatif. Bandung: Remaja Rosdakarya.

Nonaka, I. \& Takeuchi, H. (1995). The Knowledge-Creating Company: How Japanese Companies Create the Dynamics of Innovation. New York: Oxford University Press.

Nonaka, I. (1994). A Dynamic Theory of Organizational Knowledge Creation. Organization Science, Vol 5. No. 1.

Nonaka, I., Toyama, R. \& Konno, N. (2000). SECI, Ba and Leadership: a Unified Model of Dynamic Knowledge Creations. Long Range Planning, Vol 33, pp. 5-34. Available at www.elsevier.com/locate/lrp.

Parker, W.C. \& Hess, D. (2000). Teaching with and for Discussion. Teaching and Teacher Education, Vol 17, pp. 273-289.

Pollock, P.H., Hamann, K. \& Wilson, B.M. (2011). Learning Through Discussions: Comparing the Benefits of Small-Group and Large-Class Settings. Journal of Political Science Education, Vol 7, pp. 48-64. University of Central Florida.

Ramayah, T., Yeap, J.A.L. \& Ignatius, J. (2013). An Empirical Inquiry on Knowledge Sharing Among Academcians in Higger Learning Institutions. Minerva, 51, pp. 131-154. Springer Science \& Business Media Dordrecht.

Reige, A. (2005). Three-dozen Knowledge-sharing Barriers Managers must Consider. Journal of Knowledge Management, Vol 9, No. 3, pp. 18-35.

Rosen, B., Furst, S. \& Blackburn, R. (2007). Overcoming Barriers to Knowledge Sharing in Virtual Teams. Organizational Dynamics, Vol 36, No. 3, pp. 259-273. Available at www.sciencedirect.com.

Santos, V.R., Soares, A.L. \& Carvalho, J.A. (2012). Knowledge Sharing Barriers in Complex Research and Development Projects: An Exploratory Study on the Perceptions of Project Managers. Knowledge and Process Management, 19, pp. 27-38.

Sohail, M.S. \& Daud, S. (2009). Knowledge Sharing in Higher Education Institutions: Perspectives from Malaysia. The Journal of Information and Knowledge Management Systems, Vol 39, No. 2, pp. 125-142.

Hooff, B. Van den \& Ridder, Jan A. de. (2004). Knowledge Sharing in Context: Influence of Organizational Commitment, Communication Climate and CMC Use on Knowledge Sharing. Journal of Knowledge Management, Vol 8, No. 6, pp. 117-130.

Wang, S. \& Noe, R.A. (2009). Knowledge Sharing: A Review and Directions for Future Research. Human Resource Management Review, 20, pp. 115-131. 